\title{
A STUDY ON MANAGERS PERCEPTION ABOUT TRAINING AND DEVELOPMENT IN MANUFACTURING INUDSTRIES WITH REFERENCE TO CHITTOOR DISTRICT
}

\author{
C. RAJANIKANTH \& C. JYOTHSNA \\ ${ }^{1}$ Associate Professor, Department of Management Studies, Sri Venkateswara College of Engineering and Technology, \\ Chittoor, Andhra Pradesh, India \\ ${ }^{2}$ Assistant Professor, Department of Master of Business Administration, Sreenivasa Institute of Technology and
}

Management Studies, Chittoor, Andhra Pradesh, India

\begin{abstract}
Organisations and personnel both have to ameliorate and elongate their progression on the identical time for their survival and attainment of mutual desires. In this aggressive global every contemporary management has to expand the organisation through human resource development. Training develops, adjusts, and moulds the employee's information, ability, behavior, flair, and mind-set in the direction of the requirements of the process, and company. In this serious competitive globalization, technology innovation preparation is crucial for the prepared and intense business. It is the most deeply prominent that requisites to help improve the nature of the work-life of employees and improvement of the organisation. Current research acquainted on the mangers perceptiveness on training and development in manufacturing industries with a sample size of 'Six Hundred'(600), employed Analysis of Variance(ANOVA), utilized Multiple regression analysis and't' test as statistical tools for analyzing the data. The investigator focused on three regions particularly company, department, designation and observed that there may be good relation between these 3 variables and have fantastic mind-set toward training and development programmes within the corporation.
\end{abstract}

KEY WORDS: Training and Development - Employees - Designation - Department \& Organization

Received: Mar 13, 2020; Accepted: Apr 03, 2020; Published: Jul 04, 2020; Paper Id.: IJMPERDJUN2020204

\section{INTRODUCTION}

The improvement of human resource is the quiddity of development of the organization and the progression in large part lies with the great of human sources. The great of personnel depends on so many elements and training is one of the crucial elements. Human capital connects with the mastery and having excellent dexterities of the people (Becker 1964) which obtained and advanced via training, education and moxie. The training and development involves with getting to know situations in which the employee acquires additional expertise or capabilities to increase task performance. It's miles an effort to enhance the present or future employee performance by way of increasing an employee's potential to perform through mastering, commonly by means of converting the employee's mindset or growing his or her talents and wisdom (Kathy E. Kram, 2013). Training objectives enables performance improvements, discounts in mistakes, task know-how to be gained, and/or other nice organizational effects. Training is one of the maximum crucial investments as it complements the understanding, abilities, attitudes, and behavior of personnel for developing leaders faced with challenging experiences (Bulut C, 2010).

\section{REVIEW OF LITERATURE}


Amitabh Deo Kodwani, (2017) states various organizational elements that impacts training of employees who must sense responsible and accountable toward it. Vishal Arghode, Jia Wang, (2016) argued that the fact of training rendezvous from the trainers' mid-set. Eliciting trainee participation via creating an encouraging, getting to know environment and connecting with trainees through building rapport early in a training consultation. Gosim Martin Chukwu, (2016), found out that instructor variables that act as driving forces on training effectiveness. This can be a channel for enhancing the nice of training consequences thereby making training corporations greater competitive. Piyali Ghosh, Ragini Chauhan, Alka Rai, (2015), stated that different factors directly or in a roundabout way influencing switch of training, supervisor aid as a work environment variable is found to have various relationships with switch, in addition complex with the angle of time. Pattanee Susomrith, Alan Coetzer,(2015), opinioned that to examine barriers to employee contribution in intended formal training and improvement opportunities from the attitude of personnel. Anugamini Priya Srivastava, Rajib Lochan Dhar, (2015), explained that to increase the scale for insight of training fullness and assay the impact on of awareness of training depth on position behaviour: instructors' effectiveness as a mediator and the job autonomy as a diplomat.

\section{STATEMENT OF THE PROBLEM}

The current inquiry is connected with the blossoming of managerial personnel in relevance to the certain variables. The research study tries to examines the variences in the performance of managers with repect to various organizations i.e. large scale organisations, medium scale organisations and small scale organisations, various departments i.e. Personnel department, Manufacturing-department, Finance department and Marketing or Sales promotion department and others various designations i.e. General-manager's, Manager's of the organisation, Senior assistant managers, Junior assistant managers and Supervisors. It develops the relationships between development of managerial personnel and other variables namely, socio - demographic variables Organization, Department, Designation.

\section{SCOPE OF THE STUDY}

The main intention of the study is to find the development of managerial personnel of managers in relation with Organization, Department, Designation. The study attempted to predict the development of managerial personnel of managers with the help of different socio - demographic variables of 3 companies namely Amararaja Group of Companies, Lanco Industries Limited and Saint Gobain in Chittoor District respectively.

\section{RESEARCH METHODOLOGY}

5.1 Research Design: Research layout is the perceived plan and structure of research to benefit answers to analyze question. The descriptive researches describe facts and uniqueness about the populace or phenomenon being studied. The study describes the manager's ideas towards pre, during and posts training effectiveness and behavior modification and its impact and understands the reasons behind it.

5.2 Method of Study: The analyst completed the current investigation by utilizing study type as survey. A sample of 600 administrators in lieu of all classifications of enterprises is picked with the guide of following the standardized structures. The major bits of knowledge are amassed in a purposeful manner and are analyzed using legitimate quantifiable strategies and the outcomes are deciphered thusly.

\subsection{Statistical Tools Used for Analysis}

5.3.1. Development of Managerial Personnel Scale (DMPS): To measure the perception of the managers through the 
development of managerial personnel scale, which is prepared and standardized through the investigator.

5.4 The Socio-Demographic Scale (SDS): In the study Socio-Demographic Scale is created by the researcher to gauge the socio - segment factors.

5.5 Sample Selected for the Study: Total population in the study organizations was 1000 . Out of which the sample for the investigation consists of 600 managerial personnel (i.e $60 \%$ from total population 1000).

\section{STATISTICAL ANALYSIS}

\subsection{Distribution Characteristics of the Managers perception about Training and Development scores for the Whole group}

The distribution qualities called as mean (M), median (Mdn.), mode (Mo.), Range(R), quartile deviation (QD), standard deviation (SD), skewness (Sk) and kurtosis (Ku) for different divisions of the sample on Managers observation about Training and Development scores have been concentrated in this examination. The skewness and kurtosis are figured utilizing moments. For an ordinary dispersion the estimation of skewness is 0.00 and kurtosis is 3.00. The Managers recognition about Training and Development score was estimated by the Managers perception about Training and Development scale, built and normalized by the researcher, for the current investigation.

Table 6.1: Frequency Distribution of Managers Perception about Training and Development Scores for the Entire Group

\begin{tabular}{|c|c|c|c|c|c|c|}
\hline S. No & Class-Interval & Limits & Midpoint & Frq & Cfrq & Cpfrq \\
\hline 1. & $26-30$ & $25.5-30.5$ & 28 & 12 & 12 & 2.00 \\
\hline 2. & $31-35$ & $30.5-35.5$ & 33 & 184 & 196 & 32.67 \\
\hline 3. & $36-40$ & $35.5-40.5$ & 38 & 316 & 512 & 85.33 \\
\hline 4. & $41-45$ & $40.5-45.5$ & 43 & 78 & 590 & 98.33 \\
\hline 5. & $46-50$ & $45.5-50.5$ & 48 & 10 & 600 & 100.00 \\
\hline $\mathrm{N}=600, \mathrm{M}=37.15, \mathrm{Mdn}=37.00, \mathrm{Mo}=37.00, \mathrm{R}=22.00, \mathrm{QD}=2.000, \mathrm{SD}=3.390, \mathrm{~S}_{\mathrm{k}}=0.340, \mathrm{~K}_{\mathrm{u}}=0.550$ \\
\hline
\end{tabular}

Interpretation: It is seen from table - 6.1, the mean Managers perception about Training and Development score for the entire group ( $\mathrm{N}=600)$ is 37.15 . The middle and mode esteems are 37.00 and 37.00 . The greatness of skewness is 0.340 and kurtosis is 0.550 . Hence the frequency distribution of Managers perception about Training and Development scores for the whole group is slightly positively skewed.

\subsection{Factorial Design for Managers Perception about Training and Development Score}

There are 3 areas in the organization, 4 areas in the department and 2 areas in the designation. The influence of organization, department and designation on the Managers perception about Training and Development scores of managers is investigated through $3 \mathrm{X} 4 \mathrm{X} 2$ factorial design.

\section{Hypothesis - 1}

There might be no big influence of fundamental results particularly; organization, department and designation on the Managers perception about Training and Development scores of the managers.

\section{Hypothesis - 2}

From the analytical investigation it was noticed that there was no basic impact of collaboration impacts explicitly; organization, department \& designation on the Managers perception about Training and Development scores of the managers. 
Factor A: Organization (3 levels)

Factor B: Department (4 levels)

Factor C: Designation (2 levels)

Table 6.2: Results of ANOVA of 3X4X2 Factorial Design for Managers

Perception about Training and Development Scores of Managers

\begin{tabular}{|c|c|c|c|c|c|}
\hline S. No. & Source of Variance & Sum of Squares & df & Mean squares & F - Value \\
\hline 1. & A & 2.203 & 2 & 1.102 & $0.097 @$ \\
\hline 2. & B & 103.058 & 3 & 34.353 & $3.019 *$ \\
\hline 3. & C & 0.042 & 1 & 0.042 & $0.004 @$ \\
\hline 4. & A Vs B & 48.157 & 6 & 8.026 & $0.705 @$ \\
\hline 5. & A Vs C & 119.503 & 2 & 59.752 & $5.251 * *$ \\
\hline 6. & B Vs C & 3.485 & 3 & 1.162 & $0.102 @$ \\
\hline 7. & A Vs B Vs C & 62.190 & 6 & 10.365 & $0.911 @$ \\
\hline 8. & Error & 6554.560 & 576 & 11.379 & \\
\hline$* *$ Shows critical at 0.01 level *Indicates significant at 0.05 level @ Indicates not noteworthy at 0.05 level \\
\hline
\end{tabular}

Interpretation: It is ostensible from Table - 6.2, that the processed estimations of ' $F$ ' for the two factor interaction effect namely; organization Vs designation is 5.251 which is significant at 0.01 level. Thereupon hypothesis -2 is dismissed. Sticking around two factor communication impacts to be specific; organization Vs department is 0.705 and department Vs designation is 0.102 which are not significant at 0.05 level. Wherefore hypothesis -2 is accepted. The estimated values of ' $F$ ' for the three factor interaction impacts namely; organization Vs department Vs designation is 0.911 which isn't critical at 0.05 level. Ergo hypothesis -2 is acknowledged.

\subsection{Impact of Socio-Segment Factors on Managers Perception about Training and Development}

The effect of the socio-segment factors on manager's perception about Training and Development is examined. The accompanying socio-segment factors are considered for the current investigation.

- Organization

- Department

- Designation

\subsubsection{Organization}

In the current disquisition, on the reason of organization; the managers are isolated into three musters. Managers of large scale industries as Group - I, Group - II is shaped as managers of medium scale industries and Group - III is framed as managers of small scale industries. The impact of 'organization' on manager's perception about Training and Development is examined through one way ANOVA - test. The next hypothesis is framed.

Hypothesis - 3: Where there is no significant impingement on the organization with the manager's perception of the training and development. 
Table 6.3: The Impact or Impress of Organization on the Managers Perception about Training and Development

\begin{tabular}{|c|c|c|c|c|c|c|c|c|c|c|c|}
\hline \multirow{2}{*}{$\begin{array}{l}\text { S. } \\
\text { No. }\end{array}$} & \multirow{2}{*}{ Variables } & \multicolumn{3}{|c|}{$\begin{array}{c}\text { No. of } \\
\text { Observations }\end{array}$} & \multicolumn{3}{|c|}{ Mean Values } & \multicolumn{3}{|c|}{ SD Values } & \multirow{2}{*}{$\begin{array}{c}\mathbf{F} \text { - } \\
\text { values }\end{array}$} \\
\hline & & $\mathbf{I}$ & II & III & I & II & III & $\mathbf{I}$ & II & III & \\
\hline 1. & $\begin{array}{l}\text { Requirement of training for } \\
\text { managers }\end{array}$ & 200 & 200 & 200 & 2.26 & 2.10 & 2.15 & 0.59 & 0.35 & 0.83 & $3.203^{*}$ \\
\hline 2. & Process of training for managers & 200 & 200 & 200 & 2.19 & 2.05 & 2.27 & 0.68 & 0.26 & 0.78 & $6.502 * *$ \\
\hline 3. & $\begin{array}{l}\text { Ideal frequency of training for } \\
\text { managers }\end{array}$ & 200 & 200 & 200 & 6.74 & 6.95 & 7.16 & 1.51 & 1.50 & 1.60 & $3.746^{*}$ \\
\hline 4. & $\begin{array}{l}\text { Kinds of programmes for training } \\
\text { of managers }\end{array}$ & 200 & 200 & 200 & 3.41 & 3.66 & 3.43 & 0.88 & 0.68 & 0.80 & $6.223 * *$ \\
\hline 5. & $\begin{array}{l}\text { Contribution of the devices for } \\
\text { management development }\end{array}$ & 200 & 200 & 200 & 17.47 & 17.34 & 17.05 & 2.65 & 2.61 & 2.74 & 1.305@ \\
\hline 6. & $\begin{array}{l}\text { Motivation to attend the training } \\
\text { programmes }\end{array}$ & 200 & 200 & 200 & 5.01 & 5.08 & 5.16 & 1.34 & 1.30 & 1.34 & 0.604@ \\
\hline 7. & $\begin{array}{l}\text { Managers perception about } \\
\text { Training and Development }\end{array}$ & 200 & 200 & 200 & 37.07 & 37.17 & 37.22 & 3.32 & 3.21 & 3.65 & 0.095@ \\
\hline
\end{tabular}

Interpretation: It is seen from Table - 6.3 that the estimation of ' $F$ ' for the Process of training for managers and kinds of programmes for the training of managers is more noteworthy than the basic estimation of ' $F$ ' (4.65) for 2 and $597 \mathrm{df}$ at 0.01 degree of significance. Consequently Hypothesis -3 is dismissed at the 0.01 level. The figured estimation of ' $F$ ' for the requirement of training for managers and Ideal frequentness of training for managers is more prominent than the critical value of ' $F$ ' (3.01) for 2 and $597 \mathrm{df}$ at 0.05 degree of significance. Thus Hypothesis -3 is dismissed at 0.05 level. For the rest of the areas manager's recognition about Training and Development, Hypothesis -3 is acknowledged at the 0.05 level.

\subsubsection{Department}

In the newfangled exploration, on the consent of typically the department; that the manager's are fractionalized into four classes. Human resources departmental managers as Group-I, Group-II is shaped as production departmental managers, Group-III is framed as finance departmental managers, and Group - IV is framed as marketing Managers. The repercussion of the 'Department' on manager's recognition about Training and Development is examined through one way ANOVA - test. The succeeding hypothesis drafted.

Hypothesis-4: There would be no huge effect of 'department' on the managers sagaciousness about Training and Development.

Table 6.4: Impact of Department on Managers Perception about Training and Development

\begin{tabular}{|c|c|c|c|c|c|c|c|c|c|c|c|c|c|c|}
\hline \multirow{2}{*}{$\begin{array}{c}\text { S. } \\
\text { No. }\end{array}$} & \multirow{2}{*}{ Variables } & \multicolumn{4}{|c|}{ No. of Observations } & \multicolumn{4}{|c|}{ Mean } & \multicolumn{4}{|c|}{ SD Values } & \multirow{2}{*}{$\begin{array}{c}\text { F - } \\
\text { Values }\end{array}$} \\
\hline & & $\mathbf{I}$ & II & III & IV & $\mathbf{I}$ & II & III & IV & $\mathbf{I}$ & II & III & IV & \\
\hline 1. & $\begin{array}{l}\text { Requirement } \\
\text { of training } \\
\text { for managers }\end{array}$ & 150 & 150 & 150 & 150 & 2.64 & 1.83 & 2.17 & 2.04 & 0.50 & 0.50 & 0.67 & 0.50 & $59.114 * *$ \\
\hline 2. & $\begin{array}{l}\text { Process of } \\
\text { training for } \\
\text { managers }\end{array}$ & 150 & 150 & 150 & 150 & 2.07 & 2.61 & 1.81 & 2.19 & 0.53 & 0.50 & 0.51 & 0.66 & $54.668 * *$ \\
\hline 3. & $\begin{array}{l}\text { Ideal } \\
\text { frequency of } \\
\text { training for } \\
\text { managers }\end{array}$ & 150 & 150 & 150 & 150 & 6.95 & 6.99 & 6.95 & 6.89 & 1.62 & 1.55 & 1.59 & 1.42 & $0.111 @$ \\
\hline
\end{tabular}




\begin{tabular}{|c|c|c|c|c|c|c|c|c|c|c|c|c|c|c|}
\hline 4. & $\begin{array}{l}\text { Kinds of } \\
\text { programmes } \\
\text { for training } \\
\text { of managers }\end{array}$ & 150 & 150 & 150 & 150 & 3.63 & 3.31 & 3.51 & 3.55 & 0.69 & 0.86 & 0.79 & 0.80 & $4.420 * *$ \\
\hline 5. & $\begin{array}{l}\text { Contribution } \\
\text { of the } \\
\text { devices for } \\
\text { management } \\
\text { development }\end{array}$ & 150 & 150 & 150 & 150 & 17.17 & 17.61 & 17.01 & 17.34 & 2.67 & 2.64 & 2.58 & 2.79 & 1.395@ \\
\hline 6. & $\begin{array}{l}\text { Motivation to } \\
\text { attend the } \\
\text { training } \\
\text { programmes }\end{array}$ & 150 & 150 & 150 & 150 & 5.33 & 4.86 & 5.21 & 4.94 & 1.17 & 1.47 & 1.24 & 1.350 & $4.190 * *$ \\
\hline 7. & $\begin{array}{l}\text { Managers } \\
\text { perception } \\
\text { about } \\
\text { Training and } \\
\text { Development }\end{array}$ & 150 & 150 & 150 & 150 & 37.79 & 37.21 & 36.67 & 36.94 & 3.28 & 3.47 & 3.20 & 3.54 & $3.015^{*}$ \\
\hline
\end{tabular}

Interpretation: Followed from Table -6.4 that the reckoned values of ' $F$ ' for the sine qua non of training for managers, Process of training for managers, Kinds of programmes for training of managers and enthusiasm to chaperone the training programmes are greater than critical value of ' $\mathrm{F}$ ' (3.82) for 3 and $596 \mathrm{df}$ at 0.01 level of significance. Wherefore hypothesis4 to be rejected at 0.01 level. The computed value of ' $F$ ' for the manager's perceptiveness about training and development is more than critical value of ' $F$ ' (2.62) for 3 and $596 \mathrm{df}$ at 0.05 level of significance. Consequently hypothesis -4 is rejected at 0.05 level. For the remaining areas Managers perception about Training and Development, Hypothesis -4 is accepted at 0.05 level.

\subsubsection{Designation}

In the present inquisition, On the idea of designation; the manager's are disunited into 2 important groups. General-manager's, manager's and senior assistant manager's as Group-I and Group- I is formed as junior assistant manager,s and supervisors. The influence of 'designation' on Managers perception about Training and Development is investigated through ' $t$ ' - test.

Hypothesis-5: There is no significant impact of 'Designation' on the Managers perception about Training and Development of managers.

Table 6.5: Impingement of Designation on Manager's Perceptivity about Training and Development

\begin{tabular}{|c|l|c|c|c|c|c|c|c|}
\hline \multirow{2}{*}{$\begin{array}{c}\text { S. } \\
\text { No. }\end{array}$} & \multicolumn{1}{|c|}{$\begin{array}{c}\text { No. of } \\
\text { Observations }\end{array}$} & \multicolumn{2}{c|}{ Mean } & \multicolumn{2}{c|}{ SD Values } & $\begin{array}{c}\mathbf{t}- \\
\text { values }\end{array}$ \\
\cline { 3 - 9 } & & I & II & I & II & I & II & \\
\hline 1. & Requirement of training for managers & 300 & 300 & 2.18 & 2.16 & 0.58 & 0.66 & $0.262 @$ \\
\hline 2. & Process of training for managers & 300 & 300 & 2.19 & 2.15 & 0.59 & 0.66 & $0.786 @$ \\
\hline 3. & Ideal frequency of training for managers & 300 & 300 & 6.94 & 6.95 & 1.58 & 1.51 & $0.026 @$ \\
\hline 4. & Kinds of programmes for training of managers & 300 & 300 & 3.43 & 3.57 & 0.82 & 0.77 & $2.165 *$ \\
\hline 5. & $\begin{array}{l}\text { Contribution of the devices for management } \\
\text { development }\end{array}$ & 300 & 300 & 17.23 & 17.34 & 2.65 & 2.69 & $0.519 @$ \\
\hline 6. & Motivation to attend the training programmes & 300 & 300 & 5.18 & 4.99 & 1.35 & 1.29 & $1.728 @$ \\
\hline 7. & $\begin{array}{l}\text { Managers perception about Training and } \\
\text { Development }\end{array}$ & 300 & 300 & 37.14 & 37.16 & 3.36 & 3.43 & $0.060 @$ \\
\hline$* *$ Betokens significant at 0.01 level * Betokens significant at 0.05 level @ Betokens not significant at 0.05 level \\
\hline
\end{tabular}

Interpretation: Table -6.5 that the estimated values of ' $t$ ' for the forms of programmes for training of managers is higher 
than critical-value of ' $t$ ' (1.96) for 1 and 598 degree of freedom at 0.05 level of significance. Concurrently Hypothesis-5 is dismised at 0.05 level. Remaining areas of managers perception about Training and Development lesser than critical-value of ' $t$ ' (1.96) for 1 and $598 \mathrm{df}$ at 0.05 level of significance. Concurrently Hypothesis -5 is accepted at 0.05 level.

\section{FINDINGS}

- There is a significant main effect of organization at 0.05 level on the Managers perception about Training and Development and interaction effects of organization and designation at 0.01 level.

- There is significant influence of organization, department, job tenure and annual income at 0.01 level on the process of training for managers and kinds of programmes for training of managers and motivation to attend the training programmes, requirement of training for managers and contribution of the devices for management development.

- There is significant influence of organization, department, designation, job tenure, annual income and educational qualification at 0.05 level on the requirement of training for managers and ideal frequency of training for managers.

\section{RECOMMENDATIONS}

- It is suggested that the employees are to be given enough opportunities to express their views in the development of the organizations.

- The management of the organization's should buck up the ethos of employees and engagement in various company decision al activities. The organization purpose is to convey condign working policies including hours work, over time payment and payment is based on hour's.

- Organizations must provide wide-range of training and development programs and good working conditions for the employees to perform their job effectively.

- Organizations have to offer unbiased promotion omnipresent based totally on the qualification of employees and /or experience and implement equal employment opportunities without any discrimination against women, and minority or old worker.

\section{CONCLUSIONS}

Organization has a significant influence on the process of training for managers and kinds of programmes for training of managers, the requirement of training for managers and ideal frequency of training for managers. Department has significant influence on the requirement of training for managers, the process of training for managers, kinds of programmes for training of managers and motivation to attend the training programmes, manager's perception about training and development, and designation has significant influence on the kinds of programmes for training of managers. It is possible to expand, the regression equations for predicting the managers' belief about training and development with the assist of various units of independent variables.

\section{REFERENCES}

1. Amitabh Deo Kodwani, (2017) "Decoding training effectiveness: the role of organizational factors", Journal of Workplace Learning, Vol. 29 Issue: 3, pp.200-216. 
2. Anugamini Priya Srivastava, Rajib Lochan Dhar, (2015) "Training comprehensiveness: construct development and relation with role behaviour", European Journal of Training and Development, Vol. 39 Issue: 7, pp.641-662.

3. Bulut $C$, Culha $O$. The effects of organizational training on organizational commitment, International Journal of Training and Development. 2010; 14(4).

4. Gary S. Becker (1964, 1993, 3rd ed.). Human Capital: A Theoretical and Empirical Analysis, with Special Reference to Education. Chicago, University of Chicago Press.

5. Gosim Martin Chukwu, (2016) "Trainer attributes as drivers of training effectiveness", Industrial and Commercial Training, Vol. 48 Issue: 7, pp.367-373.

6. Pattanee Susomrith, Alan Coetzer, (2015) "Employees' perceptions of barriers to participation in training and development in small engineering businesses", Journal of Workplace Learning, Vol. 27 Issue: 7, pp.561-578.

7. Piyali Ghosh, Ragini Chauhan, Alka Rai, (2015) "Supervisor support in transfer of training: looking back at past research", Industrial and Commercial Training, Vol. 47 Issue: 4, pp.201-207.

8. Rajashi Ghosh, Ray K. Haynes, Kathy E. Kram, (2013) "Developmental networks at work: holding environments for leader development", Career Development International, Vol. 18 Issue: 3, pp.232-256.

9. Vishal Arghode, Jia Wang, (2016) "Exploring trainers' engaging instructional practices: a collective case study", European Journal of Training and Development, Vol. 40 Issue: 2, pp.111-127. 